Journal of Business School
$2019,2(5): 12-22$
DOI: $10.26677 / T R 1010.2019 .119$
Journal Homepage: https://www.journalbusiness.org

\title{
Identifying Factors Affecting Development Investment Product With Geographical Indications In Vietnam: Research Lychee Products
}

\author{
Cu Thanh Thuy \\ Hanoi Architectural University (HAU)
}

\begin{abstract}
This study was conducted to analyze the factors affecting investment in product development with geographical indications. These factors are divided into groups to analyze which include: price, condition of natural and human resources, the support of local government. The data for the study were collected from the survey of farmers who is growing lychee products bearing geographical indications in Vietnam. At the same time, the study also compared the difference about development investment between two groups with geographical indications and no geographical indication. The Research findings are used as a basis for proposing recommendations to improve lychee products development investments with geographical indications in Vietnam.
\end{abstract}

Keywords: Development investment, geographical indications, Vietnam

\section{Introduction}

Development investment in general and investment in product development with geographical indications in particular play an important role not only for farmers planting agricultural products but also important in promoting economic development of local as well as national.

According to statistics from the National Office of Intellectual Property, Vietnam has nearly 1,000 specialty products including agricultural, aquatic and forestry products of many localities, many products have a small scope in the region district, commune or village.

The diversity of natural conditions has created the products bearing the characteristics of the country as well as the localities, lychee is one of such products, the investment in lychee development has brought great value in the local economic restructuring, improving the lives of the households growing lychee. However, beside the results obtained from investment in lychee development in Vietnam also limitations such as the investment is not really effective, still wasted in investment. Therefore, the study of factors affecting investment in product development with geographical indications: In this case, studied about lychee products are necessary, thereby promoting investment in lychee product development in Vietnam, avoiding waste in investment and making investment more effective

\section{Overview of research}

In recent years, the content related to geographical indications (GI) is increasingly receiving the 
attention of researchers as well as policy makers. There have been many studies about geographical indications published, mainly in the form of presentations at conferences under the TRIPs Agreement or in the form of monographs, typical of which can be included in the research of Bernard O'Connor (2003), Bernard O'Connor (2004). Several studies bout the impact of geographical indication protection in Europe, Africa and some OECD countries have been carried out by a number of authors such as: Rangekar Dwijen (2002), Cerkia Bramley (2011). These studies focus on the economic and social impact of geographical indications, however, this research is stopping at exploring the socio-economic implications of geographically indications, and there is a lack of empirical evidence on the impact of socio-economic of geographical indications in order to make specific and accurate conclusions.

In view of the Grote et al (2009) the developing countries should be noted that the impetus for the development of economic and social products with a geographical indication depends largely on the specific context and impact of products bearing geographical indications may vary between countries and specific codes of different products.

Choosing exploit the effects of geographical indications, however in the study of Dominique Barjolle and colleagues (2009), the authors focus on territorial impact assessment methods (economic, social and environmental) of geographical indication systems, and the authors used data in a research program in Europe for comparison.

Also selecting a research site are European countries, Carina Folkeson (2005) selected another angle of geographical indication to conduct research. Specifically, in this study, the author considered the concept of geographical indications, clearly defined geographical indications as collective ownership, originating from a specific geographical area. Manufacturers that create products with geographical indications must ensure that, these products must carry all the qualities of the products created in the area and the quality determined by the natural conditions and soil conditions of the geographical area

India is the locality selected for research by Pradyot R. Jena, Ulrike Grot (2010) with this study the authors have contributed to clarify the theoretical issues relating to geographical indications in two ways: First, as a geographical indication in the documents provided the first experimental evidence of producing products with geographical indications. Second, this study concluded that products bearing geographical indications contribute to the welfare of households.

The economic impact of geographical indications has also been theoretically recognized by different researchers (Moschini et al. (2008); Tim Josling (2006)). Accordingly, products bearing geographical indications are produced in a geographic area that has unique climatic characteristics and uses traditional production skills, products produced in the area. The area with geographical indications is unique and not created in any other region outside the area bearing the geographical indication which is still full of quality products are produced in the correct area bearing the geographical indication.

\section{Research methodology}

\subsection{Data collection methods}

Data were collected from a survey of 188 farmers who is lychee growing in Vietnam in order to compare reciprocally between two groups of households to see the differences in factors affecting real estate investment with geographical indications and without geographical indications, the author surveyed both groups, with 188 households surveyed including: 96 households in the group with geographical indications and 92 households in to the group without geographical indication. 
The survey of households for the purpose of the review on factors affecting investment in the products development with geographical indications and without geographical indications. The evaluation results of the households will be encoded and entered into the Excel software so that the average value of the analytical scales can be calculated.

\subsection{Data analysis methods}

The collected data will be calculated and analyzed, the descriptive statistical method and the comparative method used by the author in this study. The calculated results will be interpretation to analyze issues studied

\section{Research results}

\subsection{Group human resources factors}

Human resources have an important position and role with development investment activities, the survey results of the study showed that, differ on the average value of the scale factor represents a group of human resources between the two groups with geographical indication and without geographical indications, namely:

Table 1: Statistics describing human resources group

\section{Descriptive Statistics_ with geographical indications}

\begin{tabular}{|l|l|l|l|l|l|}
\hline & $\mathrm{N}$ & Minimum & Maximum & Mean & Std. Deviation \\
\hline Education & 96 & 5 & 16 & 10.70 & 3.192 \\
\hline SL_LD & 96 & 4 & 11 & 6.05 & 3.829 \\
\hline $\begin{array}{l}\text { Valid N } \\
\text { (listwise) }\end{array}$ & 96 & \multicolumn{5}{l|}{} \\
\hline \multicolumn{7}{|l|}{ Descriptive Statistics_without geographical indications } \\
\hline \multicolumn{7}{|l|l|l|l|l|l|}{} \\
\hline Education & 92 & 5 & Maximum & Mean & Std. Deviation \\
\hline SL_LD & 92 & 2 & 16 & 10.49 & 2.838 \\
\hline $\begin{array}{l}\text { Valid } \\
\text { (listwise) }\end{array}$ & 92 & & 9 & 5.32 & 2.070 \\
\hline
\end{tabular}

Source: Analysis results from the author's research data

+ Education of the head of household:

The survey results show that educational attainment of household heads in two groups of households with geographical indications and without geographical indications is relatively similar. In particular, the group with an average educational level of 10.70 is equivalent to the 10th grade high school level; the group has no geographical indication of average education level of 10.49 .

Thus, it can be seen that the educational level in both groups of households is not high compared to the current education level, however the fact this is the level of education of the household head, usually older people (according to the survey median age is about 43-46 years old), due to the limited learning conditions in the past, this average level of education is normal because the income in their farming needs much more practical experience. 
+ Number of workers in the household: Number of workers in households partly reflects the scale and lychee acreage of household. According to the survey data, the number of workers in the household has more than 2-5 labor indications compared to the number of workers in the household without geographical indications.

Specific results: the group with geographical indications has an average number of employees of 6.05 people (with at least 4 people and most workers are 11 people); the group without a geographical indication has an average number of employees of 5.32 (at least 2 people and at most 9 people in).

\subsection{The factor of lychee price}

Price is one of the factors that influence direct investment to developing lychee, if the price is high, people tend to invest actively developed for more lychee and vice versa:

Table 2: The average value of the price factor group

Descriptive Statistics_with geographical indications

\begin{tabular}{|l|l|l|l|l|l|}
\hline & $\mathrm{N}$ & Minimum & Maximum & Mean & Std. Deviation \\
\hline Price & 96 & 22 & 38 & 25.60 & 3.469 \\
\hline $\begin{array}{l}\text { Valid N } \\
\text { (listwise) }\end{array}$ & 96 & \multicolumn{5}{l|}{} \\
\hline \multicolumn{7}{|l|}{ Descriptive Statistics_with geographical indications } & & \\
\hline & $\mathrm{N}$ & Minimum & Maximum & Mean & Std. Deviation \\
\hline & 92 & 4 & 18 & 11.04 & 2.721 \\
\hline $\begin{array}{l}\text { Price } \\
\text { Valid N }\end{array}$ & 92 & & & & \\
\hline
\end{tabular}

Source: Analysis results from the author's research data

+ Price: Through the results table we can see that there is a huge disparity in the price of the 2 groups. The group with geographical indications had an average selling price of 25.6 thousand $\mathrm{VND} / \mathrm{kg}$ and the group without geographical indications had an average selling price of 11.04 thousand VND / kg. This disparity clearly shows how much of a geographical indication will have a significant impact on people's development investment. When there are geographical indications, the price of lychee products is raised, market expands and more and more consumers know the language, use the information. Survey of Department of Science and Technology, since lychee was published geographical indication, revenue from this crop increased rapidly despite reduced area. Besides increased income for local people, geographical indications are also important and long-term legal bases contributing to increasing the accumulation value and developing the brand for lychee products. 
Journal of Business School, vol.2, issue.5, pp.12-22

\subsection{Factors of group of support local government}

Table 3: The average value of the criteria for participation in training

\begin{tabular}{|l|l|l|l|l|l|}
\hline \multicolumn{6}{|l|}{ Descriptive Statistics_with geographical indications } \\
\hline & N & Minimum & Maximum & Mean & Std. Deviation \\
\hline T2 & 96 & 2 & 5 & 3.98 & .882 \\
\hline $\begin{array}{l}\text { Valid } \\
\text { (listwise) }\end{array}$ & 96 & & & & \\
\hline Descriptive Statistics_without geographical indications & & Std. Deviation \\
\hline & N & Minimum & Maximum & Mean & 1.182 \\
\hline T2 & 92 & 1 & 5 & 2.86 & \\
\hline $\begin{array}{l}\text { Valid } \\
\text { (listwise) }\end{array}$ & 92 & & & & \\
\hline
\end{tabular}

Source: Analysis results from the author's research data

+ T2 scale: Participate in training classes: The evaluation score of the group with geographical indications for the influence of participation in training classes on development investment is 3.98 points and the group without geographical indication is 2.86 points. It can be seen that households in the group have a very high geographical indication of the effectiveness of participating in the training classes.

Table 4: The average value of criteria credit support of local government

Descriptive Statistics_with geographical indications

\begin{tabular}{|l|l|l|l|l|l|}
\hline & N & Minimum & Maximum & Mean & Std. Deviation \\
\hline T3 & 96 & 2 & 5 & 3.52 & .951 \\
\hline $\begin{array}{l}\text { Valid } \\
\text { (listwise) }\end{array}$ & 96 & & & \\
\hline \multicolumn{7}{|l|}{ Descriptive Statistics_without geographical indications } & \\
\hline & N & Minimum & Maximum & Mean & Std. Deviation \\
\hline T3 & 92 & 1 & 5 & 2.63 & .958 \\
\hline $\begin{array}{l}\text { Valid } \\
\text { (listwise) }\end{array}$ & 92 & & & & \\
\hline
\end{tabular}

Source: Analysis results from the author's research data

+ T3 scale: Credit support by local governments and banks in the province: Group with geographical indication assessment of the impact of the credit support of the local government, of banks in the province to invest in the development of households at an important level, in particular, the group has a geographical indication that assesses the impact of local government credit support of banks in the province is 3.52 points, the group without geographical indications is lower than 2.63 points. 
Journal of Business School, vol.2, issue.5, pp.12-22

Table 5: Average value of criteria to support production and business capital

\begin{tabular}{|l|l|l|l|l|l|}
\hline \multicolumn{6}{|l|}{ Descriptive Statistics_with geographical indications } \\
\hline & $\mathbf{N}$ & Minimum & Maximum & Mean & Std. Deviation \\
\hline T9 & 96 & 2 & 5 & 3.77 & .672 \\
\hline $\begin{array}{l}\text { Valid N } \\
\text { listwise) }\end{array}$ & 96 & & & & \\
\hline \multicolumn{7}{|l|}{ Descriptive Statistics_without geographical indications } \\
\hline & $\mathbf{N}$ & Minimum & Maximum & Mean & Std. Deviation \\
\hline T9 & 92 & 1 & 5 & 3.08 & 1.040 \\
\hline $\begin{array}{l}\text { Valid N } \\
\text { (listwise) }\end{array}$ & 92 & & & & \\
\hline
\end{tabular}

Source: Analysis results from the author's research data

+ T9 Scale: Support for production and business capital:

Support for production and business capital as assessed by households producing products with geographical indications is important, reached 3.77 points; the group without geographical indications underestimated the 3.08 points. For any type of business, capital is a very important factor, affecting the scale and revenue of establishments and businesses

Table 6: Average value of criteria of protectionist policies on geographical indications

\begin{tabular}{|l|l|l|l|l|l|}
\hline \multicolumn{6}{|l|}{ Descriptive Statistics_with geographical indications } \\
\hline & $\mathbf{N}$ & Minimum & Maximum & Mean & Std. Deviation \\
\hline T12 & 96 & 3 & 5 & 3.85 & .632 \\
\hline $\begin{array}{l}\text { Valid N } \\
\text { (listwise) }\end{array}$ & 96 & & & & \\
\hline Descriptive Statistics_without geographical indications & Std. Deviation \\
\hline & N & Minimum & Maximum & Mean & \\
\hline T12 & 92 & 1 & 5 & & \\
\hline $\begin{array}{l}\text { Valid N } \\
\text { (listwise) }\end{array}$ & 92 & & & & \\
\hline
\end{tabular}

Source: Analysis results from the author's research data

+ T12 scale: Policy on product protection with geographical indications of local authorities: This criterion according to households producing products with geographical indications is important, reaching 3.85 points. We can see a lot of benefits for producers to have a geographical indication as prices are stabilizing, potential consumer market, trained to improve professional qualifications etc hereby contributing 
to increasing income for households producing lychee, stimulating production households to actively invest in developing lychee for local.

\subsection{Group of natural conditions factors}

For agricultural products in general and lychee products in particular are greatly influenced by natural conditions, natural conditions directly affect development investment and thereby affect people's income. Evaluation results of the households surveyed on the impact of natural conditions to develop lychee investment as follows:

Table 7: Average value of criteria location production land

\begin{tabular}{|l|l|l|l|l|l|}
\hline \multicolumn{6}{|l|}{ Descriptive Statistics_with geographical indications } \\
\hline & N & Minimum & Maximum & Mean & Std. Deviation \\
\hline T1 & 96 & 2 & 5 & 3.76 & .855 \\
\hline $\begin{array}{l}\text { Valid N } \\
\text { (listwise) }\end{array}$ & 96 & & & & \\
\hline \multicolumn{7}{|l|}{ Descriptive Statistics_without geographical indications } \\
\hline & N & Minimum & Maximum & Mean & Std. Deviation \\
\hline T1 & 92 & 1 & 5 & 3.05 & 1.062 \\
\hline $\begin{array}{l}\text { Valid N } \\
\text { (listwise) }\end{array}$ & 92 & & & & \\
\hline
\end{tabular}

Source: Analysis results from the author's research data

+ T1 scale: Location of production land of the family: Research results show, the land position for groups without geographical indications has an average impact of 3.05 on a scale of 1 to 5 ( 1 is no impact and 5 is very large impact). As for the group with geographical indications, the family's productive land position has an important influence on their development investment, specific reviews 3.76 / 5 points. If the land position is favorable will help stimulate investment people care produced on that area and vice versa.

Table 8: Average value of criteria traffic system

\begin{tabular}{|l|l|l|l|l|l|}
\hline \multicolumn{6}{|l|}{ Descriptive Statistics with geographical indications } \\
\hline & $\mathbf{N}$ & Minimum & Maximum & Mean & Std. Deviation \\
\hline T4 & 96 & 3 & 5 & 3.61 & .671 \\
\hline $\begin{array}{l}\text { Valid N } \\
\text { (listwise) }\end{array}$ & 96 & & & & \\
\hline \multicolumn{7}{l}{ Descriptive Statistics_without geographical indications } \\
\hline & $\mathbf{N}$ & Minimum & Maximum & Mean & Std. Deviation \\
\hline T4 & 92 & 1 & 5 & 2.82 & 1.342 \\
\hline $\begin{array}{l}\text { Valid N } \\
\text { (listwise) }\end{array}$ & 92 & & & & \\
\hline
\end{tabular}

Source: Analysis results from the author's research data

+ T4 scale: Trafficsystem: The road system according to the evaluation of households producing products with geographical indications is important, reaching 3.61 points (scale: 1 if the answer is that the trafficsystem does not affect the income of the 
surveyed household, returns the value 2 if the answer is traffic system less affect, returns the value 3 if the answer is traffic systems that affect, returns the value 4 if the traffic system large affect returns the value 5 if the trafficsystem is very large affect). For groups without geographical indications, the impact of their transportation system to develop lychee investment is assessed at an average of 2.82 points. Convenient transportation system will contribute to creating favorable conditions for people when carrying out their gardening care activities, they will avoid the "shy" when investing in these lychee fields, gardens of lychee.

Table 9: Average value of criteria climate conditions

\begin{tabular}{|l|l|l|l|l|l|}
\hline \multicolumn{6}{|l|}{ Descriptive Statistics_with geographical indications } \\
\hline & $\mathbf{N}$ & Minimum & Maximum & Mean & Std. Deviation \\
\hline T7 & 96 & 2 & 5 & 3.32 & .657 \\
\hline $\begin{array}{l}\text { Valid N } \\
\text { (listwise) }\end{array}$ & 96 & & & & \\
\hline Descriptive Statistics_without geographical indications & \\
\hline & N & Minimum & Maximum & Mean & Std. Deviation \\
\hline T7 & 92 & 1 & 5 & 2.95 & 1.083 \\
\hline $\begin{array}{l}\text { Valid N } \\
\text { (listwise) }\end{array}$ & 92 & & & & \\
\hline
\end{tabular}

Source: Analysis results from the author's research data

+ T7 scale: Climate conditions: The group without geographical indications assessing the climate conditions is still the lowest among all scales with the impact assessment score of 2.95 points. This means that climate conditions have a moderate impact on their lychee investment. Natural climate conditions of Luc Ngan is relatively preferential for the development of agricultural products, not only climate but also soil, therefore, people rely more on other factors such as the market for investment decisions with this product development. With groups of geographical indications of factors point average natural conditions were 3.32 , the impact on the average level of investment decisions rather to develop products of household lychee.

\subsection{Group factors of market}

Table 10: Average value of criteria consumer products market

\begin{tabular}{|l|l|l|l|l|l|}
\hline \multicolumn{6}{|l|}{ Descriptive Statistics_with geographical indications } \\
\hline & N & Minimum & Maximum & Mean & Std. Deviation \\
\hline T6 & 96 & 2 & 5 & 3.48 & .598 \\
\hline $\begin{array}{l}\text { Valid N } \\
\text { (listwise) }\end{array}$ & 96 & & & & \\
\hline Descriptive Statistics_without geographical indications & \\
\hline & N & Minimum & Maximum & Mean & Std. Deviation \\
\hline
\end{tabular}


Journal of Business School, vol.2, issue.5, pp.12-22

\begin{tabular}{|l|l|l|l|l|l|}
\hline T6 & 92 & 1 & 5 & 2.91 & 1.201 \\
\hline $\begin{array}{l}\text { Valid N } \\
\text { (listwise) }\end{array}$ & 92 & & & & \\
\hline
\end{tabular}

Source: Analysis results from the author's research data

+ T6 scale: Consumer products market: Group with geographical indication assessment of the impact of the consumption market to invest in developing their products in important levels, specifically, the group with geographical indications assesses the impact of consumption market by 3.48 points, the group without geographical indications is lower than 2.91 points.

In which the group has a geographical indication, consumer market has much impact on development investment, lychee is a key product of Bac Giang and Hai Duong provinces, directly related to the lives of tens of thousands of farming households, is a crop alleviation of poverty and get rich, but to care for the lychee tree output is a very important factor for the product line this fresh fruit.

Table 11: Average value of T11

\begin{tabular}{|l|l|l|l|l|l|}
\hline \multicolumn{6}{|l|}{ Descriptive Statistics_with geographical indications } \\
\hline & $\mathbf{N}$ & Minimum & Maximum & Mean & Std. Deviation \\
\hline T11 & 96 & 2 & 5 & 3.76 & .880 \\
\hline $\begin{array}{l}\text { Valid N } \\
\text { (listwise) }\end{array}$ & 96 & & & & \\
\hline Descriptive Statistics_without geographical indications & Std. Deviation \\
\hline & N & Minimum & Maximum & Mean & 1.037 \\
\hline T11 & 92 & 1 & 5 & 3.32 & \\
\hline $\begin{array}{l}\text { Valid N } \\
\text { (listwise) }\end{array}$ & 92 & & & & \\
\hline
\end{tabular}

Source: Analysis results from the author's research data

+ T11 scale: Advertising, building brand development, trade promotion activities: This is one of the marketing activities that helps lychee products to be known to more customers and producers sell more products, thereby encouraging households to invest more in this product. However, according to the survey results, the group with a geographical indication evaluates promotional activities, build brand development, trade promotion to investment and development is important. Specifically, the group with geographical indications rated 3.76 points / 5 points and the group without geographical indication was 3.32 on a 5 -point scale. 
Journal of Business School, vol.2, issue.5, pp.12-22

\subsection{Scientific and technical factors}

Table 12: Average value of criteria science and technology

\begin{tabular}{|l|l|l|l|l|l|}
\hline \multicolumn{6}{|l|}{ Descriptive Statistics_with geographical indications } \\
\hline & $\mathbf{N}$ & Minimum & Maximum & Mean & Std. Deviation \\
\hline T8 & 96 & 2 & 5 & 3.92 & .902 \\
\hline $\begin{array}{l}\text { Valid N } \\
\text { (listwise) }\end{array}$ & 96 & & & & \\
\hline \multicolumn{7}{|l|}{ Descriptive Statistics_without geographical indications } \\
\hline & N & Minimum & Maximum & Mean & Std. Deviation \\
\hline T8 & 92 & 1 & 5 & 3.43 & 1.020 \\
\hline $\begin{array}{l}\text { Valid N } \\
\text { (listwise) }\end{array}$ & 92 & & & & \\
\hline
\end{tabular}

Source: Analysis results from the author's research data

+ Scale T8: Scientific and technical progress:

Both groups have an important assessment of the impact of scientific and technical progress on development investment of households, specifically, the group with geographical indications assessing the impact of scientific and technical progress is 3.92 points; the group without a geographical indication has a lower rating of 3.43 points. This is quite a high level; demonstrate awareness of the importance of scientific and technical progress to development investment of households producing lychee products. The application of scientific and technical progress in the improvement and cultivation, taking care of litchi trees will contribute to reducing manual labor time and increasing productivity, thereby contributing to increase household income.

\section{Recommendations}

To invest in lychee products development bring better results, some recommendations were proposed the following authors:

Local governments need to invest in building infrastructure to better service the production and consumption of products with geographical indications: Good infrastructure will contribute to reducing production costs and facilitating the consumption of lychee products, thereby encouraging households to continue to expand investment in products, promote product consumption. Regularly implement trade promotion with the right focus, follow to the actual needs of the province. Combining investment promotion with trade and tourism promotion in countries with commercial potential such as: China, Japan, Korea, EU countries, North America, ASEAN Integrating the provincial trade promotion program with national trade promotion program

Access to credit, loans is one of the important factors for economic development, increasing income for households producing products with geographical indications. The lack of capital will limit the ability to invest in product development bearing geographical indications, so access to capital and loans is a financial solution for 
producers, business, which can increase income for producers, thereby stimulating investment in product development bearing local geographical indications.

Organize training courses and technical training directly in caring and harvesting products bearing geographical indications to farmers, from which the employee will be more active in the production, care products, applying modern techniques to production, gradually improveing quality of labor in producing products with geographical indications.

\section{References}

Bernard O'connor (2003). Geographical indications in international and national law, monograph6, O'connor and company, Brussels

Bernard O'connor (2004). The legal protection of geographical indications, Intellectual property quarterly, No1, pp35-57

Berenguer, A (2004). Geographical origins in the world. Paper presented at the workshop Promoting Agricultural Competitiveness through Local Know-how, Proceedings of the Montpellier Workshop. Washington D.C. World Bank Group; Paris: MAAPAR; Montpellier: CIRAD.

Cerkia Bramley (2011). A review of the socio- economic impact of geographical indications: considerations for the developing words, WIPO worldwide symposium on geographical indications Conference, June, Peru

Dominique Barjolle, Marguerite Paus, Anna Perret (2009). Impacts of Geographical Indications Review of Methods and Empirical Evidence, International Association of Agricultural Economists Conference, Beijing, China

Grote, Ulrike (2009). Environmental Labeling, Protected Geographical Indications, and the Interests of Developing Countries, The Estey Centre Journal of International Law and Trade Policy, Volume 9, Number 2, pp138-154.

Moschini, G., L Menapace, and D. Pick (2008). Geographical Indications and The Competitive Provision of Quality in Agricultural Markets, American Journal of Agricultural Economics, 90(3), pp794-812

Rangnekar Dwijen (2002). The pros and cons of stronger geographical indication protection, BRIDGES, No3, pp3-6

Pradyot R. Jena, Ulrike Grot (2010). Does geographical indication (GI) increase producer walfare? A case study of Basmati rice in Northern India, the ISEE conference

Tim Josling (2006). The war on terroir: Geographical indications as a transatlantic trade conflict, JAE journal of Agricultural economics, Volume 57, issue3, pp337-363 